International Journal of Instruction e-ISSN: 1308-1470 • www.e-iji.net
July $2019 \bullet$ Vol.12, No.3

p-ISSN: 1694-609X

pp. $219-236$

Received: 29/09/2018

Revision: 25/03/2019

Accepted: 30/03/2019

OnlineFirst:25/04/2019

\title{
Local Knowledge System of Kampung Naga: A Study to Investigate the Educational Values of Indigenous People in Transmitting Religious and Cultural Values
}

\author{
Sandie Gunara \\ Department of Music Education, Universitas Pendidikan Indonesia, Indonesia \\ sandiegunara@upi.edu \\ Toni Setiawan Sutanto \\ Department of Music Education, Universitas Pendidikan Indonesia, Indonesia, \\ tonisetiawans@upi.edu \\ Febbry Cipta \\ Department of Music Education, Universitas Pendidikan Indonesia, Indonesia, \\ febbrycipta@gmail.com
}

\begin{abstract}
This study aims to investigate how indigenous music education serves as an instrument of transmitting local knowledge of religious and cultural systems situated in one of the cultural heritage sites called Kampung Naga, based in West Java, Indonesia. Indigenous music education, in the existing body of literature of local knowledge, has to date been an understudied topic compared to agriculture, local medication, language, and literature. Therefore, as an ethnographic study, the present research serves to fill that void. Data were gained by a way of observations, interviews, documentation and audio-visual recording. Couched under the analysis of local education values, music in Kampung Naga is of empirical interests. Traditional music has been transmitted from elders to the younger generation through informal education. The elders employ a local knowledge system as the basis of their teaching practice by which the younger generation constructs spiritual experience and self-introspection. Music is productively used to fortify faith and respect ancestors. In conclusion, Islamic values and Sundanese culture, in Kampung Naga, are blended to produce an educational value about God and nature.
\end{abstract}

Keywords: indigenous music education, local knowledge system, local education values, Kampung Naga, transmitting religious, cultural values

Citation: Gunara, S., Sutanto, T. S., \& Cipta, F. (2019). Local Knowledge System of Kampung Naga: A Study to Investigate The Educational Values of Indigenous People in Transmitting Religious and Cultural Values. International Journal of Instruction, 12(3), 219-236. https://doi.org/10.29333/iji.2019.12314a 


\section{INTRODUCTION}

It is undeniable that globalization has penetrated various aspects of life. As a consequence of it, globalization has a two-sided effect. On the one hand, it contributes to the betterment of social life. On the other hand, it may give rise to the erosion of local values. In response to this, it is deemed necessary to deliberate local knowledge systems (see Chikaire, 2012; Briggs, 2013; Cajete, 2015; Bar-on, 2015), which refers to a certain set of local wisdom crucial to deal with the current globalized environment. The system can be productively used, one of which, in an indigenous community.

The current studies of local knowledge system have centered on practical cases, integrating local knowledge (of an indigenous community) with a scientific concept, and discussions about the comparison between knowledge of an indigenous community and neoliberal discourses. Regarding those issues, Briggs (2013) started to wonder about deadlocked, even degraded, discussion as the issues have less impact on daily life practices. In fact, a local knowledge system has been an understudied topic. To fill this gap, more elaboration on this particular issue is called for. To that end, studies on local knowledge should be directed to focus on not only practical issues but also indigenous local education values.

A large number of works on local knowledge system of an indigenous community have been undertaken, revolving around aspects of conservation on knowledge indigenous community (see Sillitoe, 1998; Briggs, 2013; Popova, 2014; Heckenberg, 2015), intellectual property for local knowledge of indigenous community (see Masango, 2013; Tan, 2013), and pragmatic-ideology of local knowledge of indigenous community (see Bar-On, 2014). There are, hence, no significant studies on the concept of local knowledge system of the indigenous community to stimulate effective learning in a formal setting.

The present study seeks to contribute to the existing body of literature on local knowledge by constructing a conceptual understanding of local knowledge system by analyzing its educational values. The values can be implemented as the basis informal education, especially in music education. Related to this issue, Abrokwaa (1999) had conducted research on music education (concept and teaching techniques) in an African indigenous community. The study was intended to inform Western music teachers about African culture, specifically its musical tradition. In conclusion, there were fruitful suggestions on introducing and teaching of indigenous music in Westerns educational institutions.

The present study aims to broaden a local knowledge system in indigenous education topics, specifically in an indigenous community, Kampung Naga, Tasikmalaya, Indonesia. This study also identifies educational values that have been applying for hundreds of years. Therefore, types of the local knowledge system, which construct their daily life and its educational values to be implemented in formal music education at school, are the critical issues to discuss.

This study was conducted in Kampung Naga, a village inhabited by an ethnic group of Sundanese people who are vigorously upholding the customs of their ancestral. They 
sustain their culture in a significantly different manner to others. The people of Kampung Naga live in an order which is situated in modesty and local wisdom (Nurjanah, 2013; Gunara, 2017).

The present study describes, firstly, the existence of Kampung Naga. Then, it discusses its cultural ecology. The points worth pondering in this study are the findings and methodological debate on teaching terebang music in Kampung Naga as a manifestation of indigenous education. Finally, practical and empirical implications for teaching music by using local cultural approach are proposed.

\section{LITERATURE REVIEW}

Samali and Kincheloe (1990) stated that concepts of local knowledge system are flourishing in countries with significant numbers of indigenous communities (namely Africa, Latin America, and Asia). Scholars refer to the concept as local knowledge or indigenous knowledge. However, both terms have identical meaning; it is knowledge which is produced by people in a particular area. Local knowledge or indigenous knowledge is conceptualized differently by scholars or policymakers. Ramnath (2014) defined the terms as oral knowledge of indigenous people which serves information about daily activities (ancient and sacred knowledge in a non-Western community) and system of sustainable living that goes, hand in hand, with Western science.

Western scholars often associate the terms with primitive, wild, and natural contexts (Semali and Kincheloe, 1999). This argument cannot scientifically be accepted. In the author's perspective, as a Sundanese (an indigenous community), local knowledge is a cultural rationalization of daily life as foundations for individual or community to live in specific areas.

Local knowledge, for the indigenous community, is derived from life experiences by considering certain customs. The process of gaining knowledge is through observing and adapting the natural situation around them (Ascher, 2002; Barnhardt and Kawagley, 2005; Gunara, 2017). Gunara (2017) emphasized that their local knowledge system plays a significant role in determining how to interact with nature and the outside world. Moreover, local knowledge refers to the unique indigenous knowledge gained by local communities through the accumulation of experience, informal experiments, and understanding of the environment in a particular culture (Chikaire et al., 2012). The respective local knowledge system constitutes technology, social system, economic system, philosophy, learning, and governance system (see Chikaire et al., 2012; J. Abah, P. Mashebe, and D.D. Denuga, 2015).

An established local knowledge system (in an indigenous community) emanates from a high contemplation and spiritual process. Therefore, according to Battiste (2002), the knowledge becomes a sacred thing. The reason is that indigenous knowledge system of indigenous people covers spiritual relationships, relationships with natural resources, interpersonal relationship (reflected in language, social organization, values, institutions, and law (see Chikaire et al., 2012). The knowledge is created as a perpetual responsibility to be an established custom. It is safe to suggest that the local knowledge system in indigenous community needs to be passed down for the later generation. 
There are many studies on the local knowledge system in indigenous community (see Grenier, 1998; Sillitoe, 1998; Abrokwaa, 1999, Semali and Kincheloe, 1999; Thaman, 2009; Choudry, 2010; Nurjanah, et al., 2013; Kaino, 2013; Briggs, 2013; Masango, 2013; Bar-on, 2014; J. Abah and Denuga, 2015; Heckenberg, 2015; Gunara, 2017). Finally, the present study broadens the analysis of local knowledge system in an indigenous community to strengthen some missing points of previous studies.

\section{METHOD}

The design applied in this research is ethnography. This design is used to describe a culture and understanding of the way of life that comes from the views of the indigenous people of Kampung Naga. Researchers as ethnographers have explored a number of specific topics to help understand the problem directly from the support community or people who are related to the problem while considering how the informant straddles and compiles answers. Thus, the informant perspective related to the theoretical and conceptual understanding of the local knowledge system of the Kampung Naga indigenous people, by studying the values of indigenous education, especially in the field of music, becomes accurate.

Data collection was obtained by involving four types of strategies namely, observation, interviews, documentation, and audio-visual material. We spent about two periods. The first period was held from June to September 2016. Then the second period was held from January to May 2018 which aimed to enrich and expand this study. We observed his life, musical performances, and his music teaching by elders to children in Kampung Naga. We also interviewed an elder about the explanation of music learning methods based on his understanding as well as interviews with children to find out the response to music learning. We also succeeded in recording the music training and observing natural conversations between elders and children in the activity. All of the data is then interpretative in narrative form.

\section{FINDINGS}

The purpose of this study was to seek the existing body of literature on local knowledge by constructing a conceptual understanding of local knowledge system by analyzing its educational values. This point describes, firstly, the existence of Kampung Naga. Then, it discusses its cultural ecology. The points worth pondering in this study are findings and methodological debate on teaching terebang music in Kampung Naga as a manifestation of indigenous education. Finally, practical and empirical implications for teaching music by using local cultural approach are proposed.

\section{The existence of Kampung Naga}

In regard to the indigenous community, the United Nations (UN) states that indigenous people are the heirs and cultural practitioners and a unique way of connecting with people and the environment. They have different social, cultural, economic and political characteristics of the dominant society in which they live. In Law No. 6 of 2014 in the village article 97 paragraph (1), it states that the establishment of an indigenous village requires the following requirements: 
a. the unity of indigenous people and their traditional rights are still alive, whether they are territorial, genealogical, or functional;

b. the unity of indigenous people and their traditional rights is considered to be suitable for the development of society; and

c. the unity of indigenous people and their traditional rights is deemed to be ideal to the principle of the Republic of Indonesia.

Subsequently, in Article 97 paragraph (2), it is affirmed that the unity of indigenous and customary law communities as referred to paragraph (1) sub-paragraph (a) shall have territory and, at least, meet one or a combination of elements of:

a. communities whose citizens share a shared sense of belonging;

b. customary government institutions;

c. property and/or customary objects; and/or

d. the instrument of customary law norms.

Kampung Naga is a village inhabited by a group of people who are vigorously upholding the customs of their ancestral (Gunara, 2017). The people of Kampung Naga live in an order which is situated in modesty and local wisdom (Nurjanah, 2013; Gunara, 2017). They uphold their culture in a significantly different manner to others.

In addition, identity is an individual characteristic aspect of character or group characteristic aspect, which is related to their sense of self (Giddens and Sutton, 2014). In the theory of identity and social identity, the self is reflexive as it can regard itself as an object and can categorize, classify, or name itself, in certain ways, in relation to other social categories or classifications (see Sets and Burke, 2000). In social identity theory, this process is called as self-categorization (see Turner et al., 1987 in Stets, 2000), whereas, in identity theory, it is called as identification (see McCall and Simmons, 1978 in Stets, 2000). Through the process of self-categorization and identification, identity is formed. For Stets (2000), the consequences of self-categorization and identification are the emphasis on the perceived similarity between self and other group members, and the focus on the perceived difference between self and outside groups. This emphasis occurs in all attitudes, beliefs, values, affective reactions, behavioral norms, speech styles, and other traits considered to be correlated with categorization between the concerned groups (Stets, 2000).

By leaning on the theory, Kampung Naga, an indigenous community, is identified as a group of people which, in practice, implement common perception of ancestral tradition in daily life. The identification provides several characteristics in determining indigenous community, namely:

a. the legitimacy of the outside communities that directly regard them as Kampung Naga people;

b. the existence of a distinctive social structure;

c. residing in the lands of the ancestors;

d. having the same lineage, from the natives;

e. having a unique culture, including religion, government system, dress, art, life philosophy, a way of learning; 
f. living separately from other societies and rejecting cultural material from the outside;

g. having strong beliefs and respectful to the traditional chairman or elder.

Kampung Naga consists of individuals with the same cultural identity. Its characteristics are related to language, beliefs, spirituality, attitudes, behaviors, and values that are different from other societies. The cultural identity of indigenous people is also characterized by similarities in livelihoods, cultural artifacts, artistry, and more specifically the same ancestors, in which each member of the society can draw a genealogical relation to the same ancestor.

The settlement of Kampung Naga has a pattern of clusters with a wide space in the center. Kampung Naga is located on the acreage of 1.5 hectares with different heights. This situation results in the houses built are located in different parts of the land. The construction is terraced from high land to the lowest land (Nurjanah et al., 2013).

Moreover, the house is a building that belongs to the individual/family of Kampung Naga residents. Similar to all buildings in Kampung Naga, the house must be built on the surface of the land or building stage and built with face to face or back to back, extending from west to east with the door facing north or south. A similar condition applies to adjacent houses. Adjacent side is the same part as the house next to it, the edge of the house, tepas part, will co-exist with the other side of the house so that the position of the pawon (kitchen) will also co-exist with the pawon on the other hand (Hermawan, 2014).

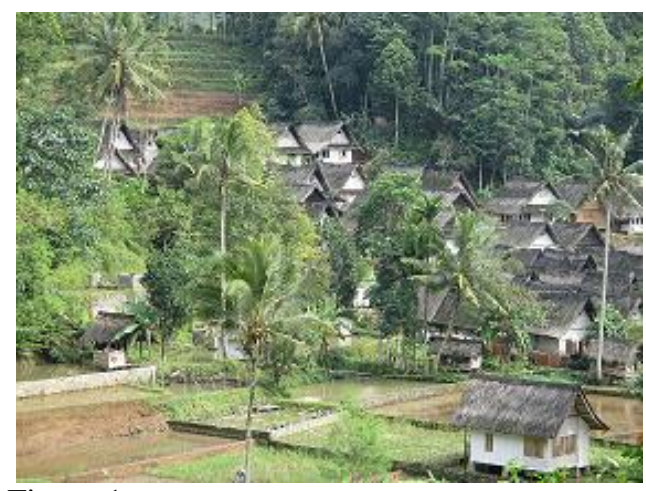

Figure 1

Kampung Naga's housing pattern. Established houses are located in different parts of the land. The construction is terraced from high land to the lowest land (Doc: Gunara, 2018)

The topography of Kampung Naga area is a combination of hill and foothills; the west part is higher than the east where the Ciwulan river flows. The condition of such land, in Sundanese, is known by the term "taneuh bahe ngetan" (land with a sloping topography to the east). For Sundanese, the land is believed to be an ideal area, because it is suitable to serve as residential and agricultural areas. The belief is rationally understandable, as it will get more morning sunshine which is very good for human health as well as the 
growth of agricultural crops. The steep slopes of the land are overcome by making séngkédan stones ranging from half a meter to six meters, and on the flat land of séngkédan, the people build a house and other village facilities (Hermawan, 2014).

Currently, the situation of Kampung Naga is still well maintained. However, due to the development of the era and the necessities of life, in general, Kampung Naga community is divided into two groups (Gunara, 2017), namely:

a. Kampung Naga community group that live in Kampung Naga residence;

b. Kampung Naga community group that live outside the settlement called Sanaga.

According to Gunara (2017), the cause of migration from Kampung Naga to outside part is (1) due to marriage with members of Kampung Naga community living outside the village, or with other members of the community outside of their community, (2) for economic reasons, so with a more practical choice, they choose to live outside Kampung Naga to open their business, (3) due to limited available land in Kampung Naga, the newly married couple prefer to settle or build a house outside Kampung Naga with the consideration that the land in Kampung Naga is not possible to rebuild the house. Therefore, if the number of families increases and no longer viable to live in one house, then the family must build a house and live in the outside of Kampung Naga. However, at certain times, they gather in Kampung Naga.

Basically, those who reside outside Kampung Naga are still bound by the village custom and remain recognized as part of their community. However, for indigenous community members, who live outside of Kampung Naga, are not bound by the terms and conditions to make the stage house and other rules (Nurjanah et al., 2013).

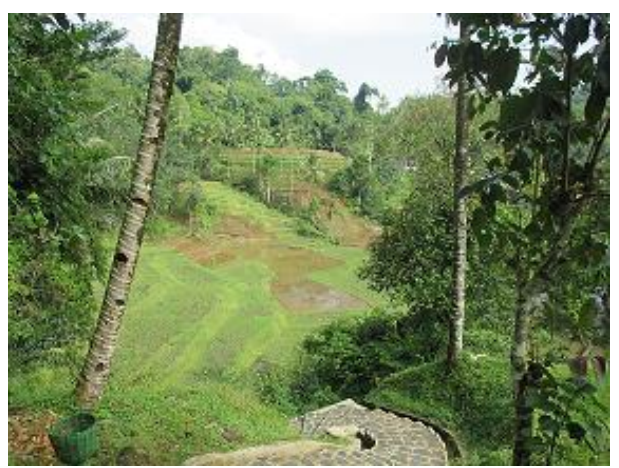

Figure 2

The road to reach Kampung Naga. Visitors must walk through hundreds of stairs. Currently, the road is well-maintained as there is fund contribution from local government (Doc: Gunara, 2018)

\section{Cultural ecology of indigenous people of Kampung Naga}

Indigenous cultures of Kampung Naga, until now, are still well-maintained. There is a high spirit in maintaining this situation of the people who are members of the customary 
community. They believe that the cultures of Kampung Naga exist to fulfill the needs of all residents. It then remains some questions about the establishment of their culture. Firstly, they all have to survive, so there is a kind of economic organization that they need. Secondly, they must adhere to customary norms in running their lives, so it takes a type of control system. Thirdly, to ascertain that the cultures of Kampung Naga survive, the elders must educate and care for their generation, so that the education system is needed.

The situation, as described above, requires a system that governs; it is informal leadership. The informal leadership is determined by conventional procedures for a long time ago. The highest leader is someone called Ki Kuncen (Mr. Ade Suherlin). He is also the elder one. His duties are as a stakeholder as well as customary managers. $K i$ Kuncen is a position passed down from generation to generation based on blood relation. It means that when Ki Kuncen has a child (commonly boy), then the child will inherit the position as kuncen. In carrying out his duties, as well as the formal leadership system where the $R W$ Chairman is assisted by the RT Chairman, Ki Kuncen is also aided by Ki Lebe (Mr. Ateng) and Ki Punduh (Mr. Ma'mun). Ki Lebe deals with any religious affairs, such as death and marriage. Ki Punduh oversees physical development affairs such as public facilities, mobilizing the community to work together, and the matters of order and security, including maintaining the behavior of the people to stick to the prevailing norms and customs.

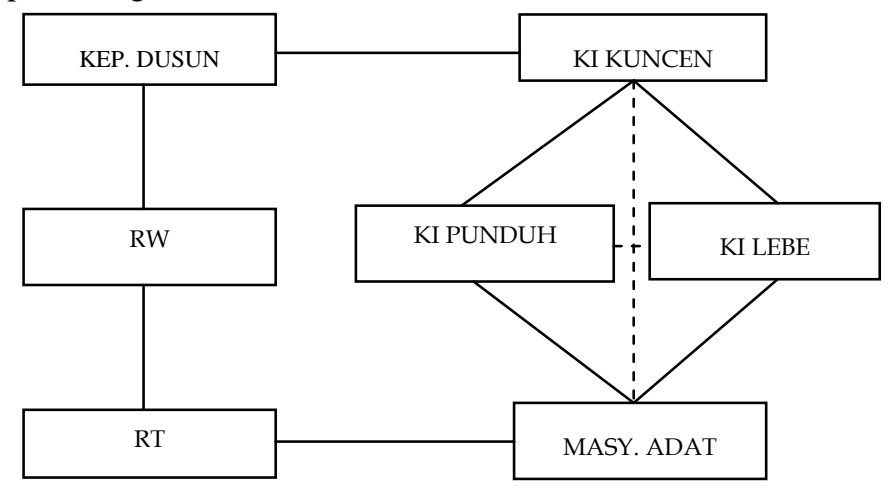

Figure 3

Informal Organization Structure of Kampung Naga.

These two leadership systems are duality. They are mutually beneficial and result from no overlapping of power as their different duties and authorities.

In practice, the two systems of leadership are duality; they are mutually beneficial and result from no overlapping of power as their different duties and authorities. Ki Kuncen and his helpers ( $K i$ Punduh and Ki Lebe) only deal with matters relating to customs and traditions that become their ancestral heritage. However, RW and RT handle all matters relating to the administration and government programs. Excellent communication system from both parties, from the system of state government and customary, can be seen in the activities of traditional ceremonies, such as basic hajat. RT is in charge of 
maintaining the situation and undertaking of the ceremony, while the ritual is led by $K i$ Kuncen. The harmony of both parties results from a positive influence on the system of government in Kampung Naga. The harmony is based on the quality of both parties to place themselves in two different positions. As indigenous people, they must submit to and adhere to tradition and their leader. As Indonesia citizen, then they must also comply with all obligations as others.

The people of Kampung Naga are Sundanese who are productive cultivators, where they produce their own food by farming on the hills. This way, they are not always dependent on nature. They have no conflict with nature; it raises a thought of nature appreciation. The appreciation and harmony of nature are formed from the patterns of three that they have been practicing as farmers.

The patterns of three in pre-modern Indonesian culture flourish in primordial societies that live by farming. The cultivators are those living from rice farming, usually in hilly areas (Sumardjo, 2011). According to Sumardjo, the mind-set of the cultivators is different from the gathering community. Nevertheless, there are still mixing traits. The people of the field no longer depend on nature because they can produce their own food by farming. However, the cultivators do not take full advantage of farming. Forest is still needed when the old fields have been unproductive due to fertility value reduction.

The patterns of three result in harmony. Harmony does not eliminate the two original entities but marries them. In marriage, men are men; women are women. Both merge as an entity that gives birth to a family: the child. Moreover, harmony is a paradoxical event; nothing is defeated, so there is no winner. Both are winners; even give birth to a new life (Gunara, 2017).

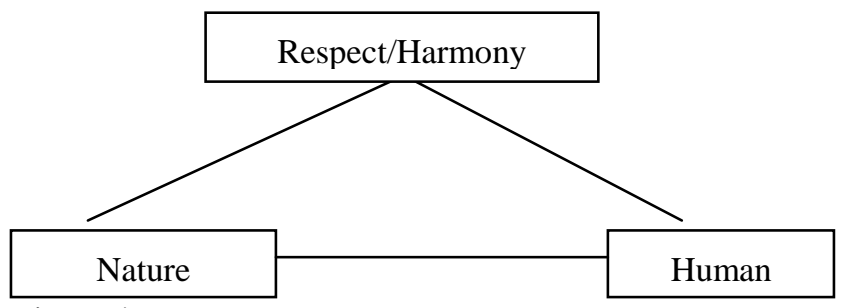

Figure 4

The pattern of three for people in Kampung Naga.

The pattern of three flourished in pre-modern Indonesian culture and developed in primordial society living by farming. The cultivators are those living from rice farming, usually in hilly areas (Gunara, 2017).

The cultural ecology of indigenous people in Kampung Naga has been built for hundreds of years. The attention to nature is genuinely inherited from generation to generation so that they are able to keep the natural resources from over-exploitation. This has led to the situation where their growing culture is inseparable from nature. Nevertheless, they continue to embrace Islam as a foundation of life. According to Nurjanah (2013), the people of Kampung Naga are a group of people who obediently hold the customs and beliefs of the ancestors. The religion they have is a neutral Islamic 
religion, which does not affiliate with any Islamic organizations in Indonesia. They are bound to Islam which is inherited from their ancestors. Even though they are Muslims, their religious practices are heavily colored by customs, beliefs, and the philosophy of life inherited from their ancestors.

Religious life in Kampung Naga is colored by various ceremonies of customs, one of which is selamatan. Ceremony and selamatan are mostly related to the respect of ancestral spirits (karuhun/leluhur) of Kampung Naga, namely Sembah Dalem Singaparna. The traditional rituals, which are always performed by the people of Kampung Naga, are the birth ceremony, tingkeban, khitanan ceremony, marriage ceremony, the ceremony of death, the ceremony of hajat sasih, the ceremony of solitude, the ceremony related to the worship of Dewi Padi, and the ceremony associated with the house (Nurjanah, 2013).

The hajat sasih ceremony is performed six times a year based on Islamic calendar calculations. The ceremonies are:

Table 1

Time to Perform Hajat Sasih Ceremony (Nurjanah et al., 2013)

\begin{tabular}{ll}
\hline ISLAMIC MONTH & DATE \\
\hline Muharam & $26,27,28$ \\
\hline Mulud & $12,13,14$ \\
\hline Jumadil Akhir & $16,17,18$ \\
\hline Rewah & $16,17,18$ \\
\hline Syawal & $1,2,3$ \\
\hline Rayagung & $10,11,12$ \\
\hline
\end{tabular}

Hajat sasih ceremony is an essential ceremony for indigenous people of Kampung Naga. All the descendants of Kampung Naga, either from within or outside the village, from various regions, always take their time to be able to attend it. The reason is that it is about the sense of obedience to their ancestors.

\section{Terebang music learning in Kampung Naga: A manifestation of indigenous education}

Local knowledge systems in the context of indigenous education (including music education) in Kampung Naga are influenced by Islamic and Sundanese principles. Mr. Entang (one of the elders in Kampung Naga) said that terebang, both terebang gembrung and terebang sejak, is music that cannot be explained by words. The music can only be felt by the soul. For example, terebang gembrung, even for the skilled or amateur players, actually is directed toward a concept of faith. The reason is that, according to Cajete (2015), indigenous educational values are a holistic and integrated process, whose cumulative effects on elders result in profound learning and commitment to communal and cultural values, to produce outstanding future leaders.

The author's personal experience on terabang gembrung training reveals some impressions. The music directs us to build spiritual experience and self-introspection. In addition, it is also productively used to have piousness and provide ancestors with 
honor. Islamic values and Sundanese culture, in Kampung Naga, seem to coalesce in producing its local knowledge system. Terebang is a means to instill their socio-cultural values into their daily life; Islam and Sundanese. Abrokwaa (1999) emphasized that the general purpose of indigenous music education is to instill socio-cultural knowledge and skills to the youth. However, this education is not organized or structured formally. The reason is that natural support and personal ability to develop is mostly personal needs.

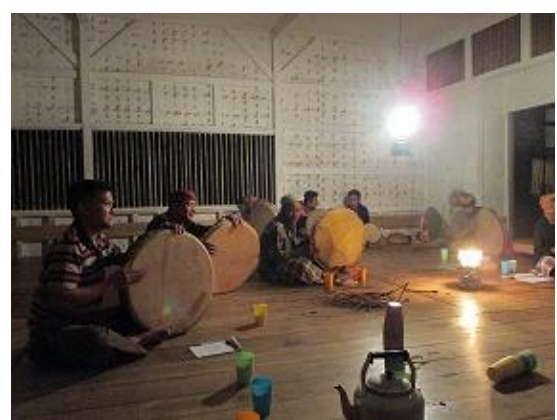

Figure 5

The author is playing terebang gembrung with the people of Kampung Naga. The author is trying to experience the essence of playing terebang gembrung. The training is held every Friday night, starting at 09:00 to 12:00 p.m. (Doc: Gunara, 2018)

The terebang gembrung music contains praises from Kitab Mulud. According to Sumardjo (2011), Sundanese Islamic mythology, in music, plays a vital role in bringing social awareness of the people of Kampung Naga as the Sundanese. This awareness is the basis for them in behaving and navigating life to the present day. In Kampung Naga indigenous community, music and life is an integral part. The practice of their life has been going on for hundreds of years. It means that their music has been inherited, from generation to generation, for hundreds of years. There is, therefore, a system of local knowledge that is effective to educate the younger generation.

The kinds of music that have been actively played by indigenous people of Kampung Naga are terebang gembrung and terebang sejak. The music is used as a companion for traditional and public activities. As a consequence, the music should continue to be taught to the next generation. It is inconceivable that their music is lost without succession. Furthermore, ritual activities in Kampung Naga are indirectly entrusted to the family, especially father. The reason is that fathers' community is regularly playing terebang gembrung and terebang sejak. Father has a responsibility to provide the knowledge of tradition and skills, not only music but also other elements of life, to the young generation. By using music, Islamic values are taught and applied in life, combined with the pattern of ancient Sundanese life. Therefore, in Kampung Naga, there is a duality of culture, namely Islam and ancient Sundanese. Those aspects are combined to be reflected in the way of life, dress, and language.

There are no reasonable resources about Islamic infiltration in producing terebang gembrung and terebang sejak. However, Ricklefs (2007) stated that Islamization in the 
area of West Java was conducted in the sixteenth century, where, at that time, the area was under the rule of, Hindu-Buddhism, the Pajajaran kingdom. In essence, these two aspects, Islam and Sunda are the principal characters of the people of Kampung Naga. Therefore, the music has colourful characters as their identity. For that reason, terebang gembrung and terebang sejak will be protected and preserved through traditional teaching to the younger generation in their environment. This is important to maintain the sustainability of identity, knowledge, cultural heritage, and the existence of Kampung Naga. In addition, this is also important because, according to Rose (1995), music representation of indigenous people (local or tradition) is a way of learning about human life. In addition to music representation of a way of life, the music also represents human activity. Music, in this sense, has become part of social life, history, and culture.

Peter Dunbar-Hall (2000) has conducted research on how the Balinese people perform Balinese Gamelan transmission. In this research, Balinese gamelan learning in Balinese society has become an act of community, although some formal schools in Bali have incorporated Balinese Gamelan as teaching materials. As similar to Bali, in Kampung Naga, terebang gembrung and terebang sejak have become ordinary activities. People come to terebang gembrung every Friday night from 09.00 to 12.00 p.m. According to the elders, the activity needs to always be held every Friday night. The students are indigenous people between the ages of $18-20 \mathrm{~s}$. As a matter of fact, the activity can be run every time, but usually after school as the students are children of 6-12 years old.

The learning activity runs in an informal situation. The children observe and then imitate what the elders do. The learning is done orally, and the musical patterns are taught with the aural approach. The musical patterns are not written down; they are all in memory and experience it from generation to generation. The teaching technique is call and response. This technique is implemented by mentioning and demonstrating patterns of beating, after that the children respond by imitating what is played by the elders. The pattern of beating is straightforward, but the difficult one is to connect the pattern with other members.

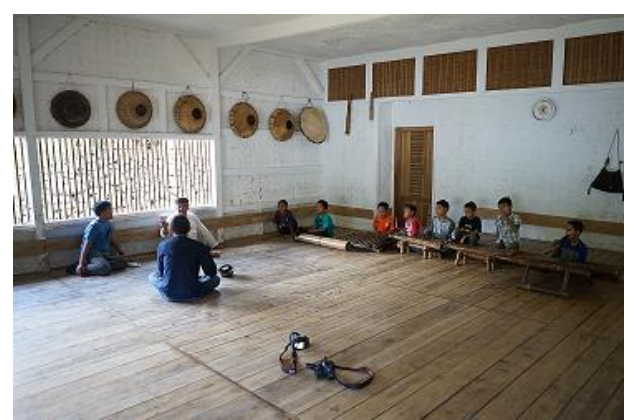

Figure 6

Mr. Entang is teaching gamelan bambu to the children of Kampung Naga. Teaching is implemented after school time (Doc: Gunara, 2018) 
There is no formal knowledge of the learning methods that elders have. All concepts are based on elders' experience. However, it is interesting that the concepts are similar to Western music learning methods, namely Kodaly, Dalcroze, and Gordon.

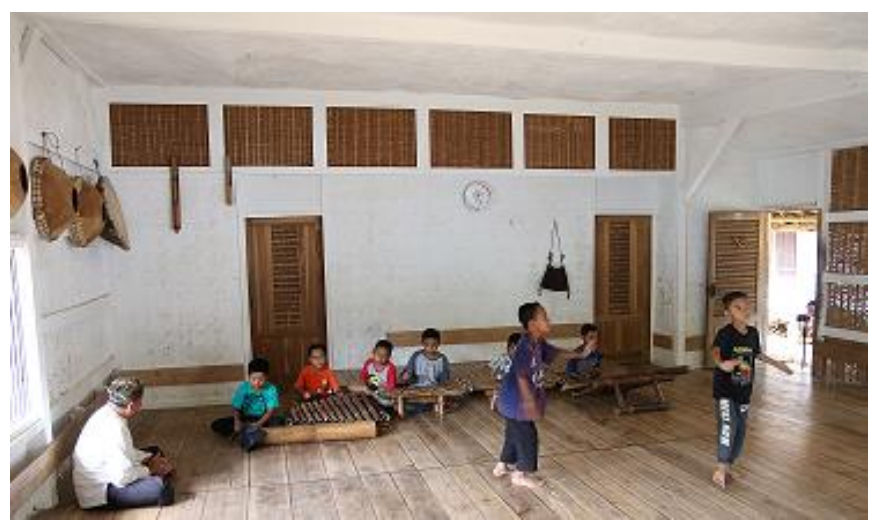

Figure 7

The children are practicing terebang and bamboo gamelan music. From an early age, they have been introduced to this music (Doc: Gunara, 2018)

There are unchanging patterns of teaching that they have long used. The patterns are $n u$ dirampa (tried, explored), nu dirasa (perceived, contemplated), and nu nyata (used, applied). Similar to Sumardjo's concept (2011) about patterns of three or tritangtu, the patterns can also be found in Kampung Naga (Gunara, 2017).

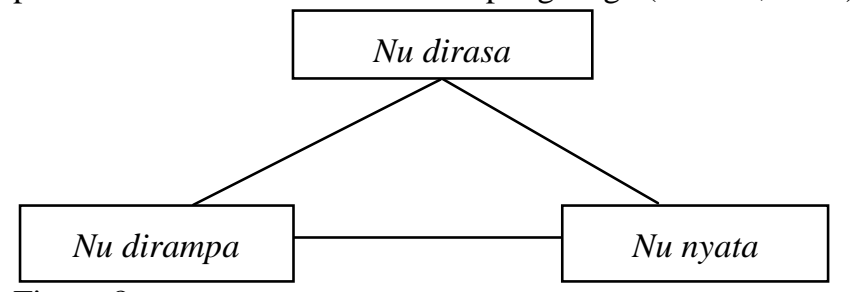

Figure 8

The patterns of three in music cultural education in Kampung Naga. This pattern is the basis of the way of thinking for all things. The base of this pattern is based on the antagonistic dualism of all things (Gunara, 2017).

The basis of cosmological beliefs of Kampung Naga, (figure 8), becomes the basis for the way of thinking for all things, namely the patterns of three (Gunara, 2017). As stated by Sumardjo (2011), the base of this pattern is based on the antagonistic dualism of all things. The sky is above; the earth is below. The sky is wet; the earth is dry. The sky is female, the earth is the man, the sky is bright, and the dark is earth. Both are separate and distant. The separation of it is not good, as it will bring death. The segregation of all things which are dualistic antagonistic should be ended by, for example, combining. Harmony makes life possible to exist. The requirement of life is the harmony of two conflicting entities, but they complement each other. 
Based on field analysis, an interpretation of the patterns can be constructed. There is an integral concept with Sumardjo (2011). Gunara (2017) stated that $n u$ dirasa (perceived, contemplated) would not eliminate the original two concepts, $n u$ dirampa (tried, explored) and nu nyata (used, applied), but unite them.

The concept of nu dirasa (perceived, contemplated) is considered to be the central part which contains two contradictory concepts, namely $n u$ dirampa and nu nyata. The concept of $n u$ dirasa (perceived, contemplated) is the liaison, medium, or intermediary that bridges the two concepts that initially contradict. The existence of nu dirasa does not allow any contradiction. The contradiction is ended by harmony as complementary (Gunara, 2017).

Gunara (2017) stated that, based on the cosmological description, the local knowledge system of indigenous people of Kampung Naga cultivates a new awareness that what the elders of Kampung Naga do to their young generation contains a noble meaning (Gunara, 2017). Thus, it is imperative to combine traditional and modern education values. According to J. Abah and Denuga (2015), indigenous education culture and indigenous people have existed for thousands of years; they engineer their own educational system before modern education was introduced by the colonialists.

Educational interaction of indigenous people in Kampung Naga is influenced by the natural conditions they have occupied from the past until today. Indirectly and for hundreds of years, nature is a source of learning. Thus the concept of education is based on the perspective of their local knowledge. This educational concept has provided capital of success and prosperity in their environment. The concept is a traditional knowledge in the form of messages and customs that are believed and passed down from generation to generation about behaving towards nature.

The general purpose of music education (terebang gembrung and terebang sejak), which is carried out informally on indigenous people of Kampung Naga, is to inculcate ancient cultural knowledge to the young generation. The elders give knowledge based on the practices of the ancestors. The curriculum comes from natural harmony. The practices have been examined in all contexts, and then the information conveyed is also the identical information from the elders. By considering the training process, terebang gembrung and terebang sejak music education serve spiritual and technical skills. In the spiritual context, the music requires full involvement of all players. The players should not be separated, both mentally and physically, with the music. The music contains Islamic and Sundanese ancestors' values.

The players are forced to blend with the music to construct spiritual attitudes. Spiritual attitudes are expressed through the appreciation of song lyrics and body movements following the rhythm of terebang. Technically, music teaches the correct position or posture when beating, singing techniques, playing techniques, and producing sounds techniques to create a concentration. All of these crucial techniques are taught either during practicing or performing

Music, for indigenous people in Kampung Naga, has become their daily routines, so it has been combined with everyday life. Its teaching practice is given in an informal 
setting. The children can learn music whenever and wherever. They can play in a bale, under the tree, or in front of the stage house. The teaching methods are performed by using oral tradition, demonstration, imitation, and memorization. The children should make total efforts with their eyes, ears, memories, and intuitions to learn music. Therefore, they must observe, hear, imagine, and memorize what the elders say.

The oral tradition has been going on for a long time. The surviving elders today acquire historical knowledge, customs, and knowledge of local values through oral traditions as well. The consequence of this method is the indigenous people of Kampung Naga have to rely on rote, the ability to hear, and then store it for a long period of time. Moreover, the utilization of onomatopoeic words in the teaching of rhythmic patterns in music is also done by the elders. This is done to mention, remember, and produce the pattern of wasps on terebang musical instruments. The sound character found on the musical instrument is sir, pak, pong, and dung. Through this practice, it is not only fun for the children but also helps them to memorize the rhythm pattern. The syllables, such as pak, pong, dung, have no particular meaning. However, these words help them to remember the rhythm pattern on terebang gembrung and terebang sejak. Moreover, those words also help children to learn hand-coordination and produce a different sound.

The theoretical and practical implication of music education in the Kampung Naga is the existence of general characteristics, especially in its teaching. The primary basis of this practice is history, where its teaching techniques never change and are passed down from generation to generation. In addition, the concept of nu dirampa (tried, explored), nu dirasa (perceived, contemplated), and nu nyata (used, applied) has survived for a long time. On the other hand, the curriculum of music education in formal school is changing based on the development of era and theories. In the context of formal education, the approach used by elders of Kampung Naga may seem obsolete, but for people in Kampung Naga, the knowledge and skills acquired through this education show individual characteristics. The concept is designed to prepare the young generation to fit their respective roles in Kampung Naga and to equip them when they, later on, become traditional elders.

\section{CONCLUSION}

The local knowledge system of indigenous people in Kampung Naga comprises patterns of collective behavior that they have thus far sustained. This fact can be interpreted by seeing Sundanese people in the recent era. Therefore, these behavioral patterns can be the source of innovation and skills that can be empowered for the general welfare of the society.

Among the many potential areas for future investigation is exploring local knowledge systems in other indigenous music education cultures. The cultures should be examined and able to be passed down as heritage. Therefore, the pattern can be adapted in the context of music education in formal school.

Furthermore, revitalization of a local knowledge system for indigenous people especially in music education at school is a necessity, as it functions as the foundation of national identity, to guide learners to be democratic and adaptive towards social and 
cultural dynamics. Finally, the concept is ideally directed to materialize a modern Indonesian society with national values.

\section{REFERENCES}

Abah, J., Mashebe, P., \& Denuga, D. D. (2015). Prospect of integrating African indigenous knowledge systems into the teaching of sciences in Africa. American Journal of Educational Research 3(6), 668-673.

Ascher, M. (2002). Mathematics elsewhere: An exploration of ideas across culture. Princeton: Princeton University Press.

Abrokwaa, C. K. (1999). Indigenous music education in Africa. In Ladislau M. Semali (Eds). What is indigenous knowledge? (pp. 191-208). London: Falmer Press.

Briggs, J. (2013). Indigenous knowledge: A false dawn for development theory and practice? Progress in Development Studies 13(3), 231-243.

Bar-On, A. (2015). Indigenous knowledge: Ends or means? International Social Work 58(6), 780-789.

Barnhardt, R., \& Angayuqaq, O. K. (2005). Indigenous knowledge system and Alaska native ways of knowing. Anthropology and Education Quarterly 36(1), 8-23.

Burke, P. J., \& Jan, E. S. (2009). Identity theory. Oxford University Press.

Battiste, M. (2002). Indigenous knowledge and pedagogy in first nation education: A literature review with recommendations. Ottawa: Indian and Northern Affairs Canada.

Chikaire, J., Osuagwu, C. O., Ihenacho, R. A., Oguegbuchulam, M. N., Ejiogu-Okereke, N., \& Obi, K. U. (2012). Indigenous knowledge system: The need for reform and the way forward. Global Advanced Research Journal of Agricultural Science, 1(8), 201209.

Choudry, A. (2010). Against the flow: Maori knowledge and self-determination struggles confront neoliberal globalization in Aotearoa/New Zealand. In Dip Kapoor and Edward Shizha (Eds), Indigenous knowledge and learning in Asia/Pacific and Africa (pp. 47-62). New York: Palgrave Macmillan.

Cajete, G. A. (2015). Indigenous education and the development of indigenous community leaders. Leadership 12(3), 364-376.

Dunbar-Hall, P. (2000). Concept or context? Teaching and learning Balinese gamelan and the universalist pluralist debate. Music Education Research 2(2), 127-139.

Gunara, S. (2017). Local knowledge system in music education culture at indigenous community Kampung Naga Tasikmalaya Regency. HARMONIA: Journal of Arts Research and Education 17(1), 48-57.

Grenier, L. (1998). Working with indigenous knowledge. A guide for researchers. Canada: International Development Research Centre. 
Heckenberg, R. (2015). Learning in place, cultural mapping and sustainable values on the Millawa Billa (Murray River). The Australian Journal of Indigenous Education 45(1), 1-10.

Hermawan, I. (2014). Bangunan tradisional Kampung Naga: Bentuk kearifan warisan leluhur masyarakat Sunda [Traditional building in Kampung Naga: Local heritage of Sundanese]. Socio Didaktika 1(2), 141-150.

Kaino, L. M. (2013). Traditional knowledge in curricula designs: Embracing indigenous mathematics in classroom instruction. Studies of Tribes and Tribals 11(1), 83-88.

Masango, C. A. (2014). Traditional knowledge and traditional cultural expressions protections: prospects in Cameroon. Information Development 30(20), 121-129.

Nurjanah, N., Koswara, D., \& Haerudin, D. (2013). Nilai-nilai kearifan lokal masyarakat Kampung Naga Tasikmalaya sebagai landasan sosial budaya pendidikan nasional [Local wisdom values of people of Kampung Naga, Tasikmalaya, as sociocultural foundation for national education]. LPPM UPI: Laporan Penelitian.

Popova, U. (2014). Conservation, traditional knowledge, and indigenous peoples. American Behavioral Scientist 58(1), 197-214.

Ramnath, A. (2014). 'Indigenous knowledge' and 'science' in the age of globalization. IIM Kozhikode Society \& Management Review 3(1), 101-107.

Rose, A. M. (1995). A place for indigenous music in formal music education. International Journal of Music Education 26(1), 39-54.

Ricklefs, M. C. (2007). Sejarah Indonesia modern: 1200-2004 [Modern Indonesia history: 1200-2004]. Penterjemah: Satriono Wahono, Bakar Bilfagih, Hasan Huda, Miftah Helmi, Joko Sutrisno, Has Manadi. Jakarta: PT Serambi Ilmu Semesta.

Semali, L. M., \& Joe. L. K. (1999). What is indigenous knowledge? New York and London: Falmer Press.

Sumardjo, J. (2011). Sunda: Pola rasionalitas budaya [Sunda: Cultural rationality patterns]. Bandung: Kelir.

Silitoe, P. (1998). The development of indigenous knowledge: A new applied anthropology. Current Anthropology 39(2), 223-252.

Stets E. J., \& Peter J., B. (2000). Identity theory and social identity theory. Social Psychology Quarterly 63(3), 224-237.

Tan, L. (2013). Intellectual property law and the globalization of indigenous cultural expressions: Maori Tattoo and the Whitmill versus Warner Bros. Case. Theory, Culture \& Society 30(3), 61-81.

Thaman, K. H. (2009). Towards cultural democracy in teaching and learning with specific references to Pacific Island Nations (PINs). International Journal for the Scholarship of Teaching and Learning 3(2), 6. 
Law No. 6 the Year 2014 regarding villages (Undang-Undang No. 6 Tahun 2014 Tentang Desa).

www.un.org. Indigenous peoples at the UN. Available at https://www.un.org/development/desa/indigenouspeoples/about-us.html. 